\title{
Description and Operation of the A3 Subscale Facility
}

\author{
G.P. Saunders ${ }^{1}$ \\ Jacobs Technology Group, Stennis Space Center, MS, 39529 \\ D.G. Varner ${ }^{2}$ \\ NASA Test Operations Group, Jacobs Technology, Stennis Space Center, MS, 39529 \\ and \\ J.B. Grover ${ }^{3}$ \\ National Aeronautics and Space Administration, Stennis Space Center, MS, 39529
}

\begin{abstract}
The purpose of this paper is to give an overview of the general design and operation of the A3 Subscale test facility. The goal is to provide the reader with a general understanding of what the major facility systems are, where they are located, and how they are used to meet the objectives supporting the design of the $\mathbf{A 3}$ altitude rocket test facility. This paper also provides the reader with the background information prior to reading the subsequent papers detailing the design and test results of the various systems described herein.
\end{abstract}

\section{Nomenclature}

$\begin{array}{ll}\text { SSC } & =\text { Stennis Space Center, MS } \\ S D T & =\text { Subscale Diffuser Test Project } \\ \text { SSD } & =\text { Subscale Diffuser } \\ J S S & =\text { J2-X Simulator Rocket } \\ E 3 C 1 & =\text { Refers to test cell } 1 \text { at test facility E3 at the E-complex at SSC } \\ E 3 C 2 & =\text { Refers to test cell } 2 \text { at test facility E3 at the E-complex at SSC } \\ L H & =\text { Liquid Hydrogen } \\ \text { LOX } & =\text { Liquid Oxygen } \\ G O X & =\text { Gaseous Oxygen } \\ G H & =\text { Gaseous Hydrogen } \\ G N & =\text { Gaseous Nitrogen }\end{array}$

\section{Introduction}

$\mathrm{T}$ HIS document provides a general overview of the A3 Subscale Test Facility located at test facility E3 at Stennis Space Center, MS. The goal is to provide the reader with a general understanding of what the major facility systems are, where they are located, how they are used to meet test objectives supporting the design of the A3 altitude rocket test facility. This document also serves as prerequisite reading to subsequent papers detailing the design of the various unique facility systems and important test results.

The A3 altitude rocket test facility, currently under construction at SSC, is being built to support the development of the J2-X upper stage engine. The J2-X engine is the upper stage engine on the Constellation program's ARES I and ARES V vehicles. A general description of the Constellation program is given in Reference 1. The A3 facility must be capable of starting, maintaining, and shutting down the J2-X engine at a simulated altitude of $100,000 \mathrm{ft}$. The engine must also be hot fired for duration of $600 \mathrm{sec}(10 \mathrm{~min})$.

The purposes of the A3 Subscale Test Facility (SDT) are to verify the aerodynamic performance of the exhaust train, which consist of a rocket diffuser, $1^{\text {st }}$ stage (or Y-stage) steam ejector and diffuser, and a $2^{\text {nd }}$ stage (or Z-stage)

\footnotetext{
${ }^{1}$ A3 Subscale Test Project Manager, Building 3226, Stennis Space Center, MS, 39529, Senior Member.

${ }^{2}$ Lead Field Engineer, E3 Test Team, Building 4010, Stennis Space Center, MS, 39529.

${ }^{3}$ Test Conductor, E3 Test Team, Building 4010, Stennis Space Center, MS, 39529.
} 
steam ejector and diffuser, and to obtain the design heat flux for the various elements of the exhaust train (rocket diffuser, $1^{\text {st }}$ stage ejector diffuser, elbow, $2^{\text {nd }}$ stage ejector diffuser, and sub-sonic exit diffuser).

\section{Facility Description}

The A3 SDT currently occupies both cells 1 and 2 of the E3 facility at SSC, E3C1 and E3C2. E3C2 is used as the steam generation cell while $\mathrm{E} 3 \mathrm{C} 1$ houses a scale version of the $\mathrm{A} 3$ test cell, exhaust train, and $\mathrm{J} 2-\mathrm{X}$ engine. The steam generation system at $\mathrm{E} 3 \mathrm{C} 2$ is a LOX/GH fueled combustor with an integral water injection system capable of producing $20 \mathrm{pps}$ of steam at pressures from 150-450 psig and temperatures from 350-750 deg F. The A3 subscale diffuser (SSD) hardware installed at E3C1 is geometrically accurate to scale from the throat of the JSS rocket thru the exit of the exhaust train. The JSS rocket is a pressure fed LOX/GH rocket designed to match the oxidizer-fuel ratio, total chamber pressure, and overall nozzle area ratio of the J2-X LOX/LH engine. A simplified schematic of E3C1 and C2 is shown in Figure 1 and a photo of the test setup is shown in Figure 2.

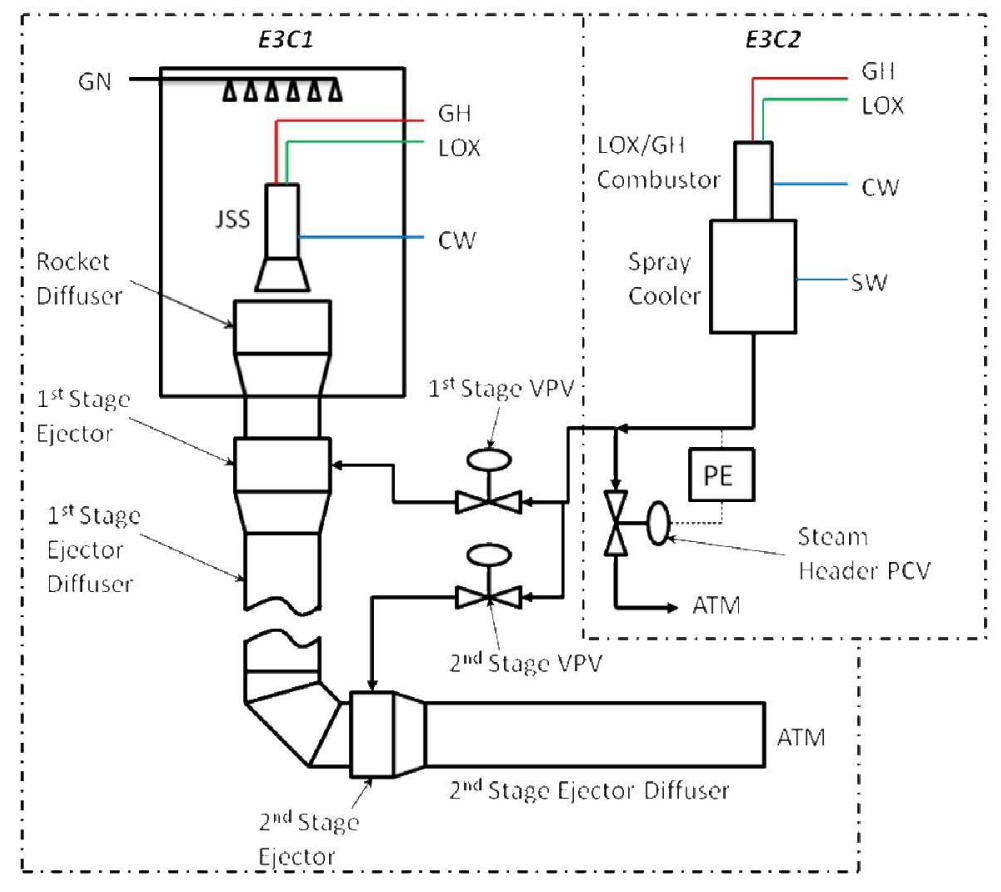

Figure 1. Simplified Schematic of E3C1 and E3C2

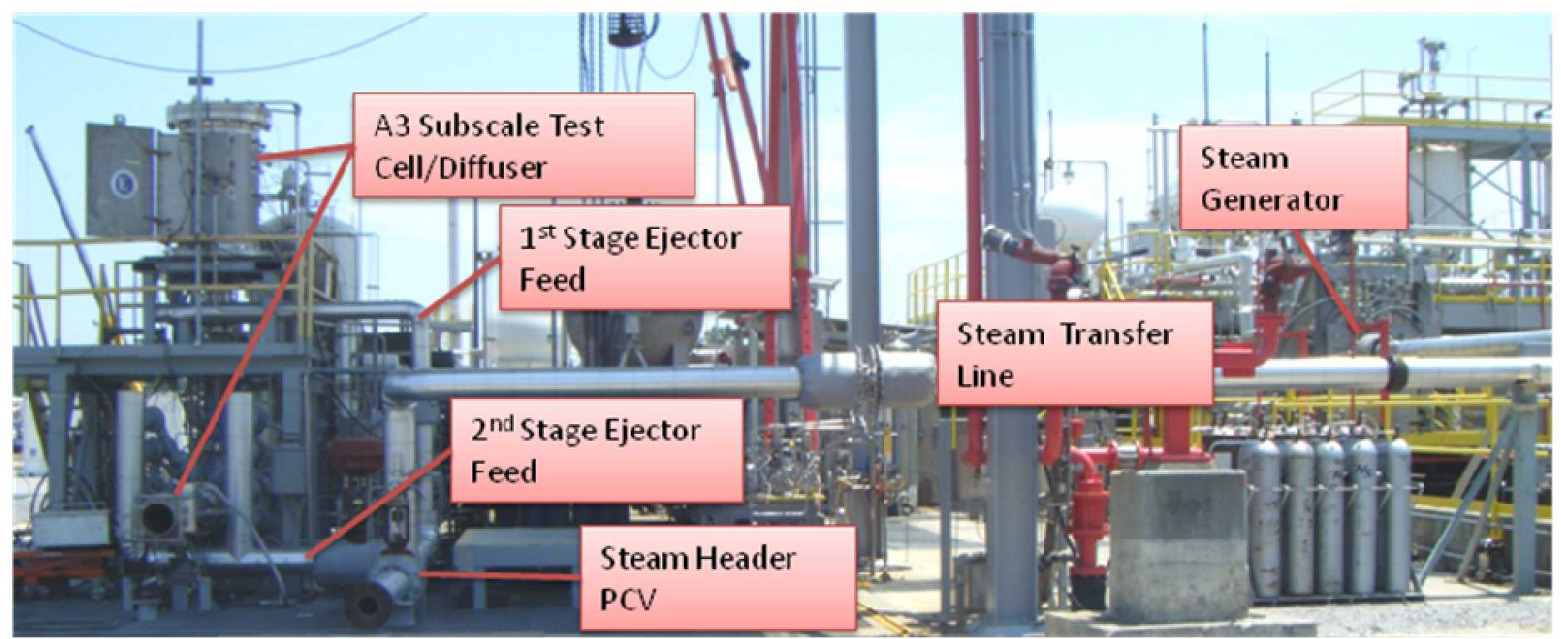

Figure 2. A3 SDT Layout

American Institute of Aeronautics and Astronautics 


\section{A. Steam Delivery}

The steam generation system at $\mathrm{E} 3 \mathrm{C} 2$ is a LOX/GH fueled combustor with an integral water injection system capable of producing $20 \mathrm{pps}$ of steam at pressures from 150-450 psig and temperatures from $350-750 \mathrm{deg} F$. The steam generator combustor is ignited using a GOX/GH spark igniter (previously an Estes solid rocket). Water is injected into the combustor exhaust gases just downstream of the combustor thru a spray cooler. The resulting steam is then transferred to E3C1. Once at $\mathrm{E} 3 \mathrm{C} 1$, the combustor pressure (or steam feed pressure) is controlled using a hydraulic actuated, closed loop pressure

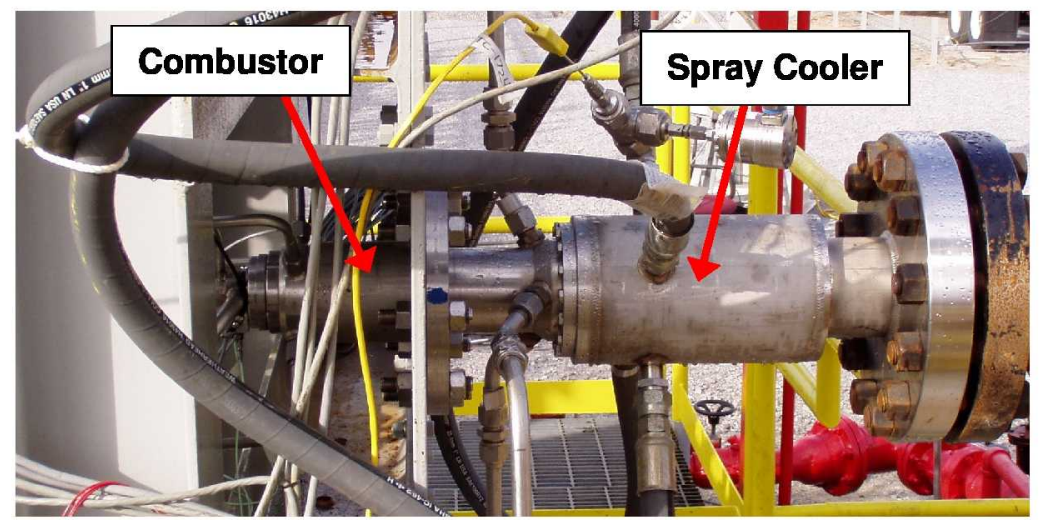

Figure 3. LOX/GH Steam Generator Hardware

feedback, globe valve. Steam flow to the $1^{\text {st }}$ and $2^{\text {nd }}$ stage ejectors is controlled via a pair of pneumatically actuated, variable position, globe valves. The $2^{\text {nd }}$ stage feed valve provides the $2^{\text {nd }}$ stage ejector 0 to $16 \mathrm{pps}$ of steam at pressure from 0 to $350 \mathrm{psig}$. The $1^{\text {st }}$ stage feed valve provides the $1^{\text {st }}$ stage ejector 0 to $2.2 \mathrm{pps}$ of steam at pressures from 0 to 400 psig. Figure 3 shows the steam generator combustor and spray cooler. Figure 4 shows the back of the combustor with its spark igniter. A detailed description of the design and activation of the LOX/GH steam generator is contained in Reference 2.

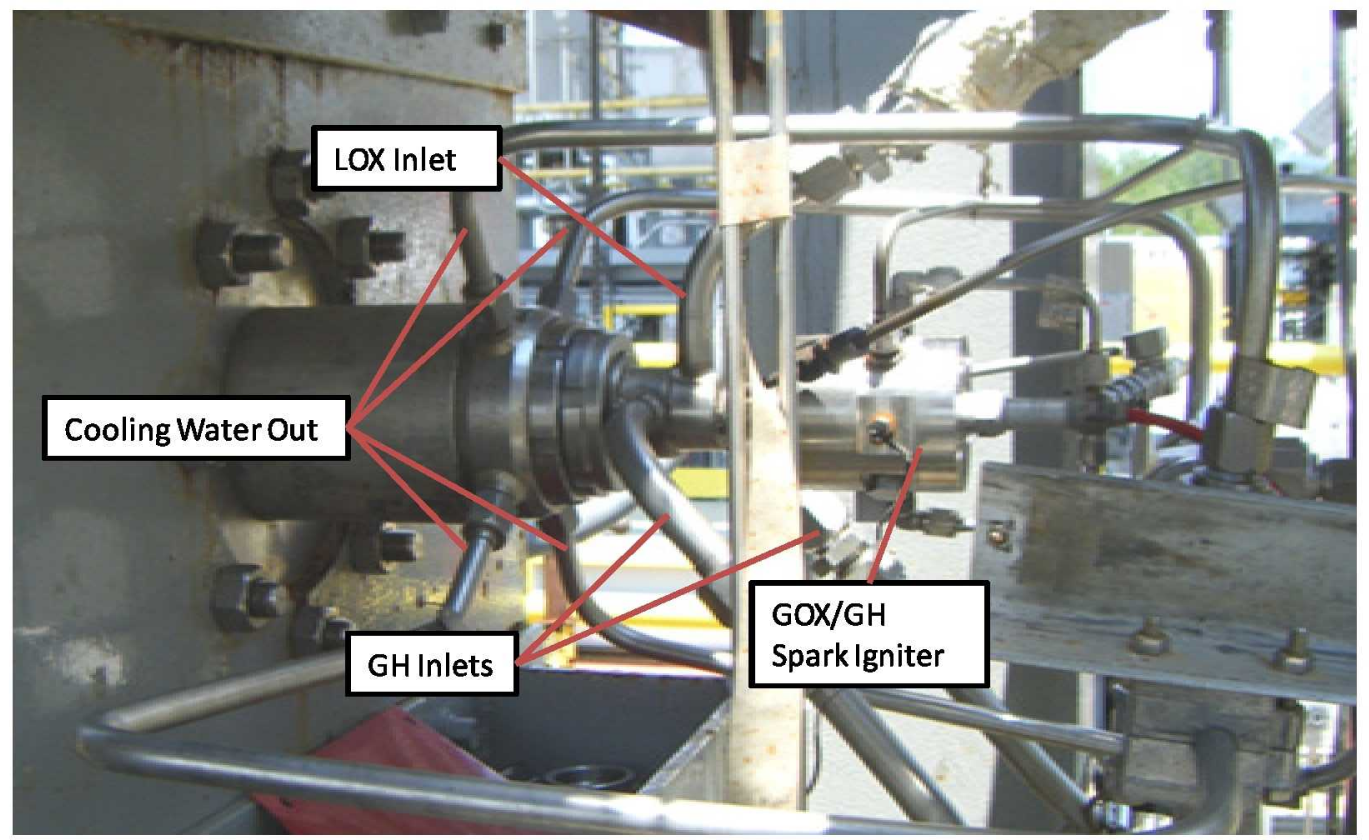

Figure 4. LOX/GH Steam Generator Igniter and Inlet Tubing

\section{B. A3 Subscale Diffuser (SSD)}

The A3 subscale diffuser test article is a scale version of the A3 test facility design. It has a geometrically accurate internal aerodynamic flow path. The scale was selected to maximize the use of common pipe stock in the construction of the SSD. The SSD is un-cooled and is capable of withstanding full steam flow indefinitely and rocket hot fire for approximately six seconds while the full scale design utilizes a water-cooled diffuser system to sustain the required 600 second rocket burn. The SSD is outfitted with numerous axial and circumferential instrumentation ports. All instrumentation ports were made identical and multifunctional with the ability to accept high response pressure transducers, high response coaxial thermocouples, or pneumatic sense lines for low 
frequency pressure measurements. Figure 5 shows a clear view of the scale diffuser during assembly of the facility. A detailed description of the design of the A3 subscale diffuser is contained in Reference 3.

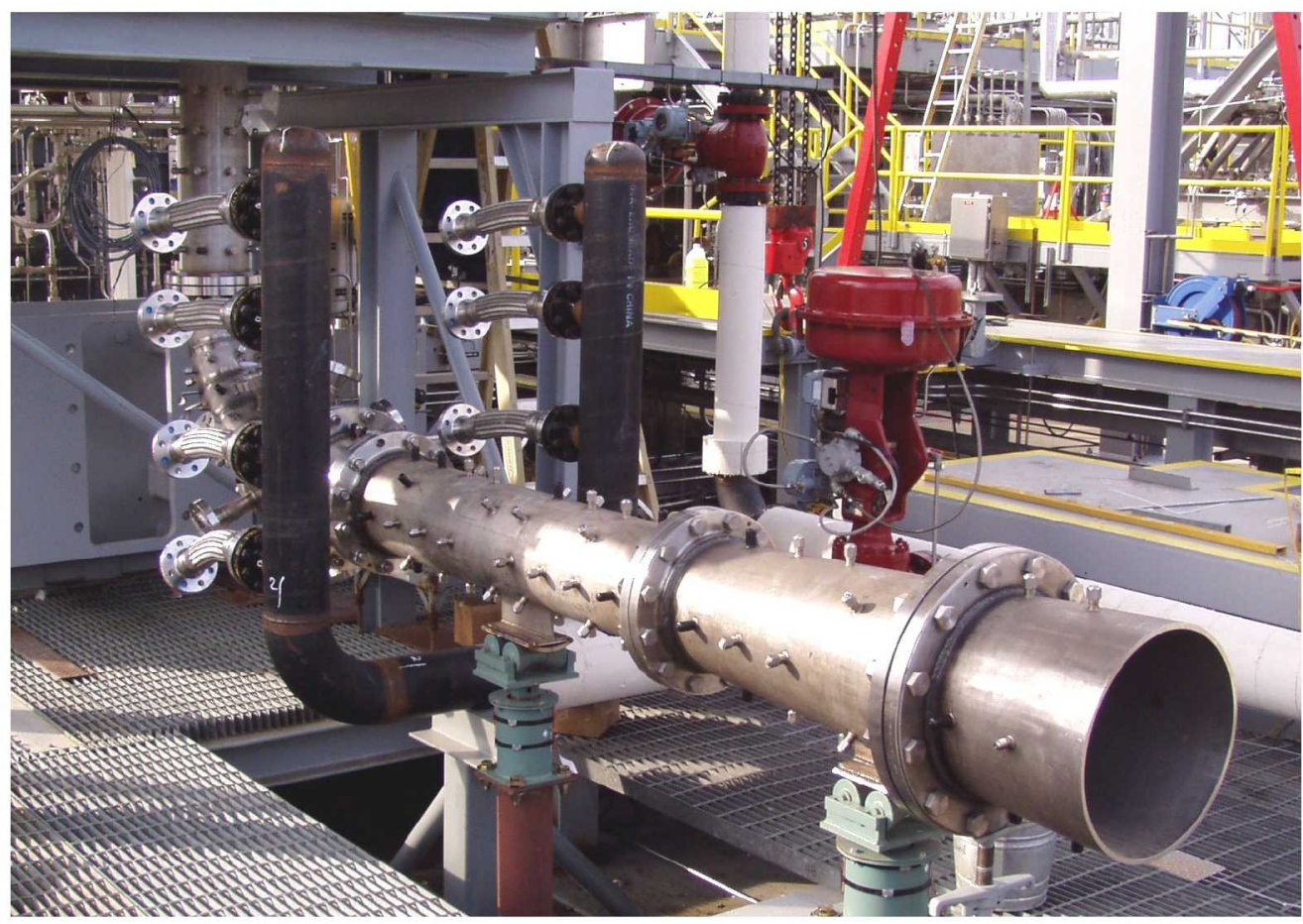

Figure 5. View of Subscale Diffuser During Construction

\section{J2-X Simulator Rocket (JSS)}

The J2-X Simulator Rocket (JSS) is a pressure fed LOX/GH rocket in the $1,000 \mathrm{lbf}$ thrust class. The JSS has a geometrically accurate aerodynamic flow path from the rocket throat to the nozzle exit. The JSS has a water-cooled copper liner which contains the nozzle throat and the first supersonic section of the nozzle. An un-cooled stainless steel nozzle extension attached to the motor housing extends the nozzle to the nozzle exit plane. The JSS is ignited using a GOX/GH spark ignition system which supplies hot gas to the combustion chamber. The JSS also has manually adjustable gimbal mounts to allow stationary firing at gimbal angles of 3.5 and 7.0 degrees in four directions. A detailed description of the design, activation, and operation of the JSS is contained in Reference 4. Figure 6 shows the JSS as currently installed in the test cell.

\section{Instrumentation}

Three separate data systems are used to obtain data for the SDT project. The SSC E3 facility low speed data acquisition system $(250 \mathrm{~Hz})$ is used to obtain primary facility data such as steam generator and JSS feed pressures, temperatures, flow rates, etc. A stand alone 48 channel high speed data acquisition system is used to obtain high response pressure and temperature data from the A3 subscale diffuser at $10 \mathrm{kHz}$. Lastly, two 16 channel high accuracy Scanivalve transducer "bricks" are used to obtain steady state static

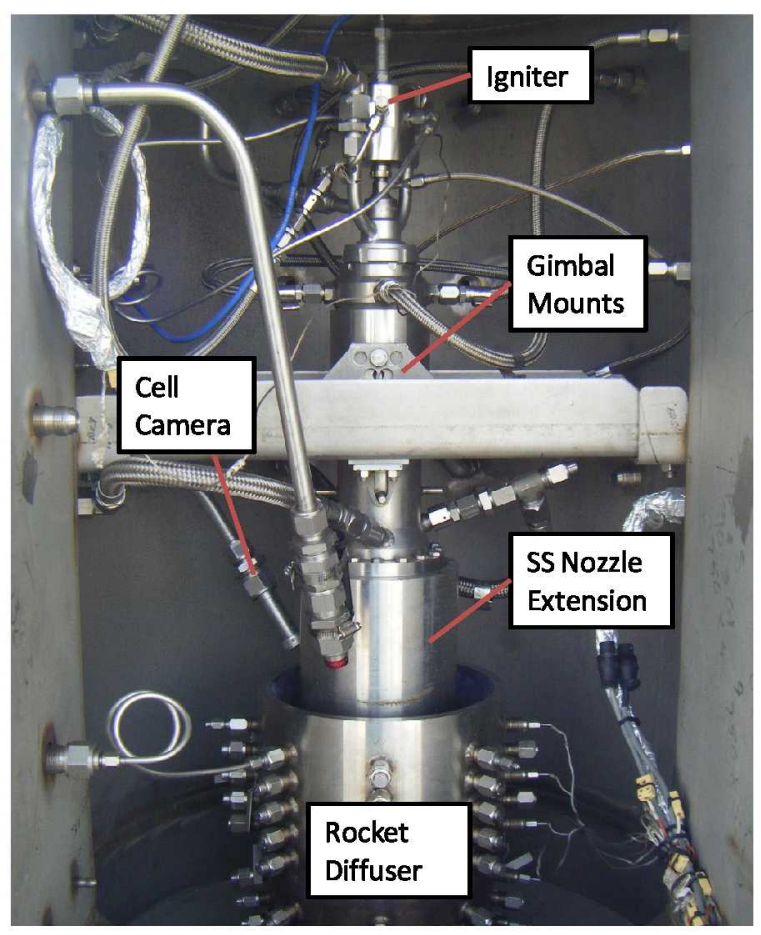

Figure 6. JSS Rocket Installed 
pressure distributions along the diffuser exhaust train. Figure 7 shows a Scanvalve module and a high response thermocouple both installed and alone.

\section{High Response Pressure Transducers}

Piezoresistive pressure transducers are used for the high response absolute pressure measurements in the exhaust train. The transducers employed silicon strain gauges bonded to a machined silicon diaphragm. The transducers have a manufacturer's quoted accuracy of $0.5 \%$ of full scale output and maximum temperature limit of $500 \mathrm{deg} F$.

\section{High Response Thermocouples}

Type $\mathrm{K}$ high response coaxial surface mount thermocouple probes are used to obtain high response internal diffuser wall temperatures for the purpose of calculating diffuser heat flux rates. The coaxial thermocouples consist of a small wire of Alumel coated with a 0.0005 inches thick ceramic insulator of high dielectric strength swaged in a tube of Chromel P. The thermocouples have a recommended temperature range of -450 to $2500 \mathrm{deg} F$. The thermocouple junction is obtained by installing the thermocouple slightly protruding through the pipe wall then fairing the probe back flush with the wall surface with a soft grinding stone. A so called sliver junction is created by the grinding process yielding a response time on the order of 100 micro-seconds $(10 \mathrm{kHz})$.

\section{Scanivalve Pressure Transducers}

Two, 16 channel transducer modules, or "bricks", are used to obtain low response static pressure measurements along the length and circumference of the exhaust diffuser ducting. The units are stand alone analog-to-digital devices requiring only power and communication via Ethernet connection. Each module contains 16 individual temperature compensated piezoresistive pressure sensors with a quoted accuracy of $0.05 \%$ of full scale output.

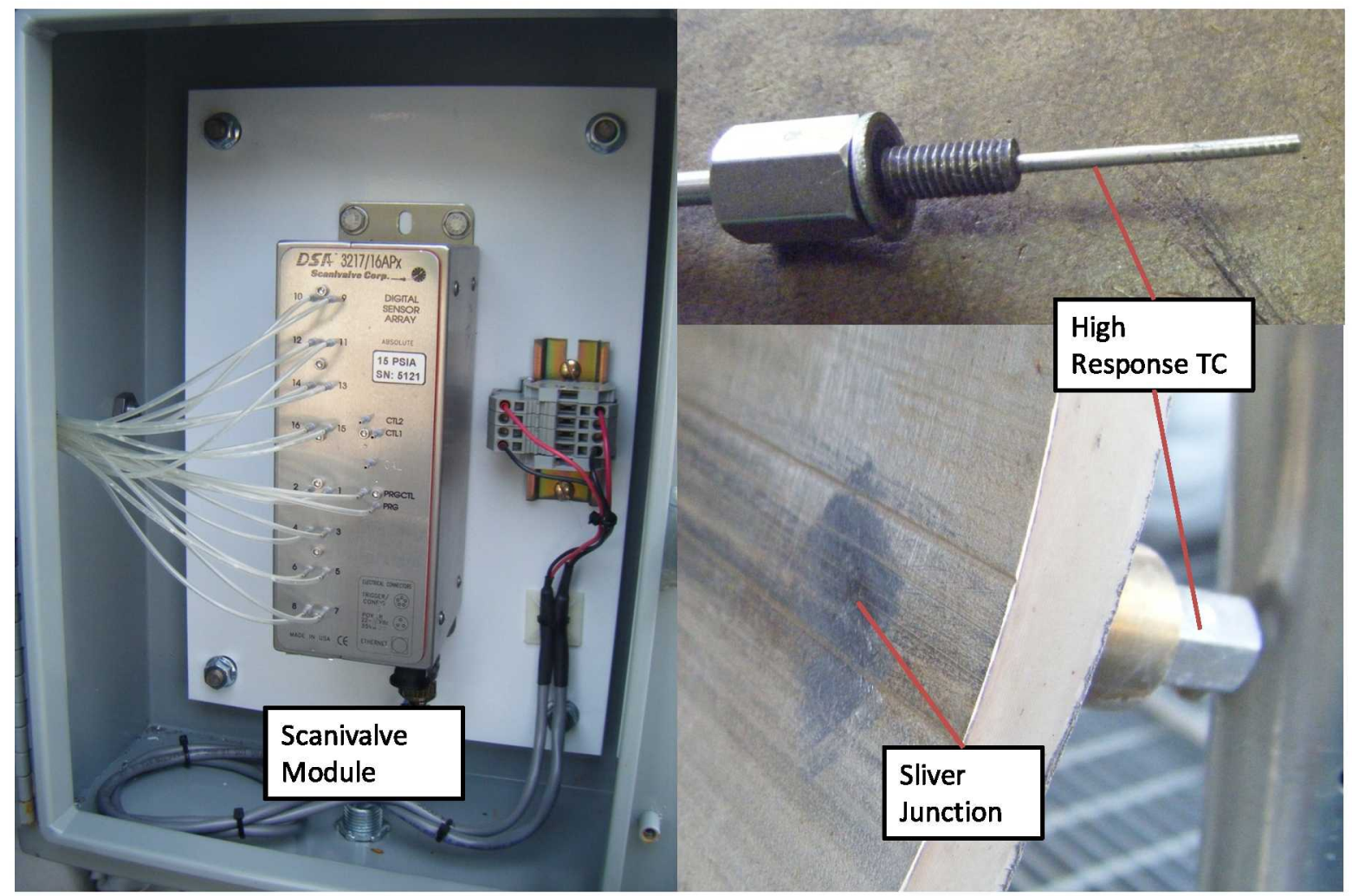

Figure 7. Scanivalve and High Response Thermocouple 


\section{Description of Operations}

This section describes in general what and how the various facility systems are used to meet various test objectives.

\section{A. Ejector Aerodynamic Performance Testing}

Ejector aerodynamic performance data is obtained by running the steam generator system only and varying the ejector steam feed pressures and secondary gas pumping load. The goal is to generate "standard" ejector performance curves, namely ejector suction pressure, $p_{\text {cell }}$, versus ejector driving pressure, $p_{\text {tse, }}$ with and without a secondary gas pumping load.

\section{Performance Testing of the Second Stage Ejector}

The $2^{\text {nd }}$ stage (z-stage) ejector feed valve is set to a fixed position while the $1^{\text {st }}$ stage ejector is set in the closed position. The steam generator in $\mathrm{E} 3 \mathrm{C} 2$ is then started to produce superheated steam. The steam header pressure control valve is activated to maintain a constant pressure. The system is then allowed to blow through the $2^{\text {nd }}$ stage ejector with the valve partially open until the steam system is sufficiently heated to maintain superheated steam in the $2^{\text {nd }}$ stage ejector plenum. The $2^{\text {nd }}$ stage steam feed valve is slewed slowly toward the closed position and back to obtain the ejector performance curve. The valve is moved sufficiently slow that the system can be considered quasisteady.

Secondary load pumping performance is then obtained by repeating the above scenario with addition of gaseous nitrogen into the test cell. This was done for several different nitrogen injection flow rates up to approximately $20 \%$ of the nominal steam ejector flow rate.

\section{Performance Testing of the First Stage Ejector}

The $1^{\text {st }}$ stage (y-stage) ejector was designed to operate against the lower backpressure created by the $2^{\text {nd }}$ stage ejector, therefore it was necessary to run the $2^{\text {nd }}$ stage ejector at its nominal design point in order to perform $1^{\text {st }}$ stage ejector testing. The $2^{\text {nd }}$ stage (z-stage) ejector feed valve is preset to achieve nominal $2^{\text {nd }}$ stage ejector plenum pressure while the $1^{\text {st }}$ stage ejector is set to a fixed position. The steam generator in $\mathrm{E} 3 \mathrm{C} 2$ is then started to produce superheated steam. The steam header pressure control valve is activated to maintain a constant steam manifold pressure. The system is then allowed to blow through both ejector stages until the steam system is sufficiently heated to maintain superheated steam in both the $1^{\text {st }}$ and $2^{\text {nd }}$ stage ejector plenums. The $1^{\text {st }}$ stage steam feed valve is slewed slowly closed and back to obtain the ejector performance curve. Again, the valve is moved sufficiently slow that the system can be considered quasi-steady.

Secondary load pumping performance is then obtained in the same fashion as the for the $2^{\text {nd }}$ stage ejector. A detailed discussion of the ejector design and performance test results can be found in Reference 5 .

\section{B. Rocket Diffuser Aerodynamic Performance Testing}

Rocket diffuser performance testing requires the operation of both the steam generator at $\mathrm{E} 3 \mathrm{C} 2$ and the firing of the J2-X simulator (JSS) rocket housed at E3C1. The $2^{\text {nd }}$ stage (z-stage) ejector feed valve is preset to achieve nominal $2^{\text {nd }}$ stage ejector plenum pressure while the $1^{\text {st }}$ stage ejector feed valve is set to overdrive the $1^{\text {st }}$ stage ejector to minimize system heat up time. The steam generator in $\mathrm{E} 3 \mathrm{C} 2$ is then started to produce superheated steam. Once superheated steam temperatures are obtained in the ejector plenums, the $\mathrm{E} 3 \mathrm{C} 1$ sequence is initiated.

To fire the JSS, an initial test cell purge and LOX bleed through the engine is utilized to obtain cryogenic temperatures at the injector interface. Simultaneously, the $1^{\text {st }}$ stage ejector feed valve is moved to obtain the desired altitude simulating test cell pressure. The test cell purge is shutoff and the JSS is then fired for approximately five seconds. The use of the GOX/GH spark ignition system allows the JSS to be restarted up to three times during one steam run. JSS firings occur at $\mathbf{3 0}$ second intervals to allow water injection into the diffuser between firings to cool the exhaust train elbow back to ambient temperature.

Secondary load pumping performance is obtained similar to the methods described for ejector performance testing. Rocket diffuser performance testing has been performed in the vertical orientation and at engine gimbal angles of 3.5 and 7 degrees in three directions (north, south, and west). Note that the facility exhaust is due north. Detailed discussion of the rocket diffuser aerodynamic performance tests are contained in Reference 6.

\section{Exhaust Train Heat Flux Testing}

Exhaust train heat flux data is obtained in conjunction with rocket diffuser aerodynamic testing. High response surface thermocouples are used to obtain transient inner pipe wall surface temperature used to calculated heat flux. 
There are 29 available high response thermocouple channels, therefore thermocouples are moved test-to-test to obtain valuable axial and circumferential heat flux distribution data with particular attention paid to the high heat flux regions in the elbow and rocket diffuser. Also, temperature indicating paint is used on the external surface of the diffuser elbow and the internal surface of the rocket diffuser to identify high heat flux regions and aid in required thermocouple placement.

Reduction of the coaxial thermocouple data to heat flux is performed by a numerical technique that assumes onedimensional heat conduction, finite wall thickness, and temperature dependent thermal properties of the wall and thermocouple. The thermodynamic properties of the thermocouple must be similar to those of the pipe wall. A detailed description of the data analysis techniques and test results are available in References 7 and 8.

\section{Conclusions}

A general description of the facility and operation of the A3 Subscale Diffuser test-bed has been given. While limited in detail, this document serves as an orientation to the facility and the general method of testing prior to reading subsequent papers detailing the design of the J2-X Subscale Simulator (JSS), LOX/GH Steam Generator, and A3 Subscale Diffuser Test Article, and describing test results from Ejector Performance Testing and Rocket Hot Fire Testing.

\section{References}

${ }^{1}$ J. Ryan, C.A. Mulkey, N.G. Raines, G.P. Saunders, “An Overview of the A3 Subscale Diffuser Test Project", AIAA-20084365.

${ }^{2}$ G.P. Saunders, C.A. Mulkey, S.A. Taylor, "Design and Activation of a LOX/GH Chemical Steam Generator", AIAA-20095007.

${ }^{3}$ G.P. Saunders, “A3 Subscale Diffuser Test Article Design”, AIAA-2009-5010.

${ }^{4}$ G.P. Saunders, N.G. Raines, D.G. Varner, "Design, Activation, and Operation of the J2-X Subscale Simulator (JSS)", AIAA-2009-5098.

${ }^{5}$ G.P. Saunders, D.A. Wagner, “A3 Subscale Steam Ejector Performance Testing”, AIAA-2009-5100.

${ }^{6}$ G.P. Saunders, J. Yen, “A3 Subscale Rocket Hot Fire Testing”, AIAA-2009-5099.

${ }^{7}$ J. Yen, G.P. Saunders, D.A. Wagner, "Transient Heat Load Estimate for the A3 Supersonic Rocket Diffuser Using Surface Temperature Measurement", AIAA-2009-5012.

${ }^{8}$ J. Yen, G.P. Saunders, D.A. Wagner, "Error Analysis of the Surface Heat Flux Calculation for the A3 Supersonic Diffuser", AIAA-2009-5011. 